\title{
Seismic signals from large, tabular icebergs drifting along the Dronning Maud Land coast, Antarctica, and their significance for iceberg monitoring
}

\author{
Myrto PIRLI, ${ }^{1}$ Kenichi MATSUOKA, ${ }^{2}$ Johannes SCHWEITZER, ${ }^{3}$ Geir MOHOLDT ${ }^{2}$ \\ ${ }^{1}$ Skjetten, Norway \\ ${ }^{2}$ Norwegian Polar Institute, Fram Centre, Tromsø, Norway \\ ${ }^{3}$ NORSAR, Kjeller, Norway \\ Correspondence: Myrto Pirli <myrto.pirli@gmail.com>
}

\begin{abstract}
In this study, we analyze a large dataset of seismic signals, recorded by station TROLL in Dronning Maud Land, Antarctica. The signals, recorded in April-December 2012, came from sources near the edge of the ice shelves, at distances of $230-500 \mathrm{~km}$ from TROLL. The sources, which moved westward with time, could be associated with four large, tabular icebergs, drifting between $15^{\circ} \mathrm{E}$ and $8^{\circ} \mathrm{W}$. Combining the seismological data with information from satellite remote sensing, we find that one-third of the signals can be attributed to individual icebergs. The trajectories of three of the associated icebergs are known through iceberg-tracking databases, whereas the fourth, a fragment of one of the other three, is untracked, and only scarce information is available from satellite imagery. The observed seismic signals exhibit a wide variety of frequency characteristics, from unstructured episodes to occurrences of iceberg harmonic tremor. Although we are not able to determine the exact cause of the signals, we classify them into five classes on a phenomenological basis. This study demonstrates the potential of regional seismic networks for iceberg monitoring as supplementary resources to information obtained with remote-sensing technologies.
\end{abstract}

KEYWORDS: Antarctic glaciology, icebergs, seismology

\section{INTRODUCTION}

Antarctic large, tabular icebergs are formed from calving at the coastal front of the ice shelves around the continent. Some soon become grounded, whereas others begin to drift, steered by ocean currents, winds, waves and their own shape and structure (e.g. Kubat and others, 2005). Icebergs are not only tracked for navigational safety (e.g. Romanov and others, 2011), but also because icebergs and their drift affect freshwater flux in the ocean (e.g. Silva and others, 2006), the distribution and formation of sea ice and polynya (e.g. Martin and others, 2007), and fluctuations in primary production (e.g. Arrigo and others, 2002; Schwarz and Schodlok, 2009). Icebergs can also deform the sea-floor by scouring (e.g. Lien and others, 1989), which may damage sea-floor installations (e.g. Dowdeswell and Bamber, 2007 and references therein). Smith (2011) provides an overview of these processes.

Large, tabular icebergs are routinely tracked using different techniques, and databases of daily or biweekly positions are compiled for each of them. The US National Ice Center (NIC) uses satellite imagery to track recently sighted, large icebergs on a weekly basis. Brigham Young University (BYU), Provo, UT, USA, provides a more complete (daily) database of Antarctic iceberg positions, through the Scatterometer Climate Record Pathfinder (SCP) project. Tracking products can be complemented by satellite imagery that provides additional information (e.g. iceberg orientation and position relative to the ice-shelf edge or other icebergs). The Appendix provides more details on iceberg-tracking services, and relevant satellite imagery availability.

During their drift and general evolution, icebergs can radiate elastic waves. Depending on the location of the source, the radiated energy may travel partly in the water as a hydroacoustic wave before reaching the ice sheet or the solid Earth, where it continues as a seismic wave. Seismic emissions from icebergs have been recorded at local (MacAyeal and others, 2008a), regional (Müller and others, 2005; Jansen, 2008; Martin and others, 2010) and teleseismic distances (Martin and others, 2010). At teleseismic distances $(>2000 \mathrm{~km})$, the signals are mostly hydroacoustic (e.g. Talandier and others, 2002; Chapp and others, 2005; Evers and others, 2013), since the sound channel in the ocean favors the propagation of energy to very long distances. In fact, iceberg hydroacoustic signals seem to constitute the dominant noise source within the oceanic sound spectrum in the Southern Hemisphere (Matsumoto and others, 2014). Correspondingly, seismic signals from icebergs represent an additional component of seismic noise in the polar regions, and, as such, hold potential for structural studies with passive imaging techniques (e.g. Zhan and others, 2014 and references therein) and studies of wave propagation (e.g. MacAyeal and others, 2015).

Several different mechanisms are under discussion to explain the observed iceberg signals. For signals within the $0.8-20 \mathrm{~Hz}$ frequency range, the proposed mechanisms include repeated discrete stick-slip sub-events when an iceberg is moving against objects, such as other icebergs or an ice shelf (MacAyeal and others, 2008a), shoaling bathymetric features (e.g. Martin and others, 2010) or the ocean floor (e.g. Talandier and others, 2002); iceberg fracturing (Martin and others, 2010); or elastic vibrations from water flowing under the appropriate conditions through the iceberg's crevasses (Müller and others, 2005; Jansen, 2008). For lower-frequency signals, ocean swell has been suggested as a driving mechanism (MacAyeal and others, 2006). Identifying the processes that generate the seismic signals can offer additional information to that 


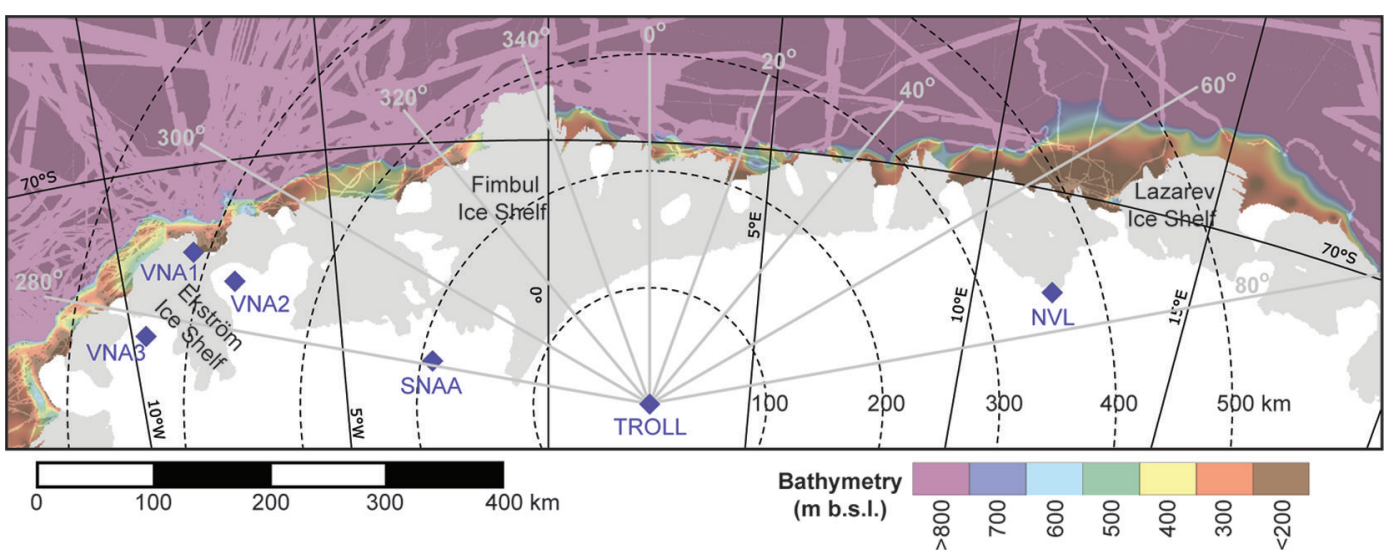

Fig. 1. The study area in Dronning Maud Land. Grounded ice is white and ice shelves are grey (Fretwell and others, 2013). Color scale denotes bathymetry intervals in meters below sea level (Arndt and others, 2013). Darker colors denote interpolated water-depth areas, while lighter colors denote areas where measured bathymetry data are available. Diamonds mark the locations of the seismic stations used in this study. Concentric dashed circles indicate distances in $100 \mathrm{~km}$ intervals from TROLL, whereas grey lines show $20^{\circ}$ backazimuth (station-tosource azimuth) intervals for TROLL.

provided by routine iceberg tracking, such as the structure of a specific iceberg (e.g. the existence of tunnels or crevasses), locations and time of iceberg calving, seabed scouring, calving and possible deformation fronts along the ice shelf where icebergs have scraped. Such events are hard to detect using current satellite techniques due to clouds, interval of satellite coverage or having occurred underwater.

The coast at Dronning Maud Land (DML), Antarctica, is characterized by semi-continuous ice shelves that extend to within a few tens of kilometers from the continental shelf break (Fig. 1). In this shallow region (bathymetry information from Arndt and others, 2013), icebergs drift westwards following the direction of the Antarctic Coastal Current near the ice-shelf edge (e.g. Aoki, 2003 and references therein), and can potentially scrape the seabed.

In this study, we analyze and classify seismic signals recorded at stations in DML from April to December 2012. We associate these signals with particular icebergs drifting along the DML coast, and investigate whether such signals can be used to complement satellite-based iceberg tracking, by revealing additional information about iceberg structure and processes.

\section{DATA AND METHODS}

The permanent, regional seismographic network in DML is very sparse, reflecting the geographic distribution of research

Table 1. Technical characteristics of the seismic stations

\begin{tabular}{lccc}
\hline Station & $\begin{array}{c}\text { Sampling rate* } \\
\mathrm{s}^{-1}\end{array}$ & Sensor type & $\begin{array}{c}\text { Recording range } \\
\mathrm{Hz}\end{array}$ \\
\hline TROLL & 100 & STS-2.5 & $120 \mathrm{~s}-50 \mathrm{~Hz}$ \\
SNAA & 20 & STS-2 & $120 \mathrm{~s}-10 \mathrm{~Hz}$ \\
VNA1 & 50 & CMG-3ESP & $120 \mathrm{~s}-25 \mathrm{~Hz}$ \\
VNA2 & 50 & CMG-3ESP & $120 \mathrm{~s}-25 \mathrm{~Hz}$ \\
VNA3 & 50 & CMG-3ESP & $120 \mathrm{~s}-25 \mathrm{~Hz}$ \\
NVL & 20 & SKD & $25 \mathrm{~s}-3 \mathrm{~Hz}$ \\
& & &
\end{tabular}

\footnotetext{
*Samples per second for the data channels used in this study.

${ }^{+}$Frequency range of registration, based on sensor characteristics and sampling rate.
}

bases (Fig. 1). In February 2012, a high-quality, permanent, three-component, broadband station (TROLL) was added near the Norwegian research station Troll (Schweitzer and others, 2014). TROLL, installed on bedrock, operates on a continuous basis, with near-real-time data transmission. All TROLL data can be downloaded from ORFEUS (Observatories and Research Facilities for European Seismology) via the European Integrated Data Archive (EIDA) portal (http:// www.orfeus-eu.org/eida/eida.html).

In this study, we primarily analyze data from this new station between April and December 2012. In addition, we use seismic data from station SNAA at the South African station SANAE IV, and occasionally from stations VNA1, VNA2 and VNA3 at the German station Neumayer III, and station NVL at the Russian station Novolazarevskaya (no data were available from the Indian seismic station MAIT, near NVL, and the seismic array around VNA2). Table 1 summarizes the station characteristics for the data used herein.

Iceberg signals are usually easily distinguishable from earthquake signals, since the waveforms of the latter are organized in well-developed seismic phase groups and are typically not characterized by high dispersion. The same applies to icequakes. However, if only the seismic waveform is considered, iceberg signals can be mistaken for noise (e.g. from strong wind) and hydroacoustic waves (T-phases), mainly due to their highly dispersive character. An inspection of the spectral characteristics of the signals solves these ambiguities by highlighting the frequency range of the signals and their dispersion patterns (e.g. Müller and others, 2005, supporting online material; Talandier and others, 2006; Dziak and others, 2010). The best way to achieve this is by using the spectrogram of the seismic data. As a first analysis step, we go through 4 hour TROLL spectrograms (window length of $1000 \mathrm{~s}$, with $75 \%$ overlap), but for interesting signals the spectrogram construction settings are adjusted to enhance, as far as possible, its resolution. Examples of waveforms and corresponding spectrograms are provided in Figure 2.

To determine the source location of the signals, we estimate the backazimuth (i.e. the station-to-source direction measured against north) and the station-source distance. To calculate the backazimuth, we use threecomponent (Schweitzer, 2013) and frequency-wavenumber 

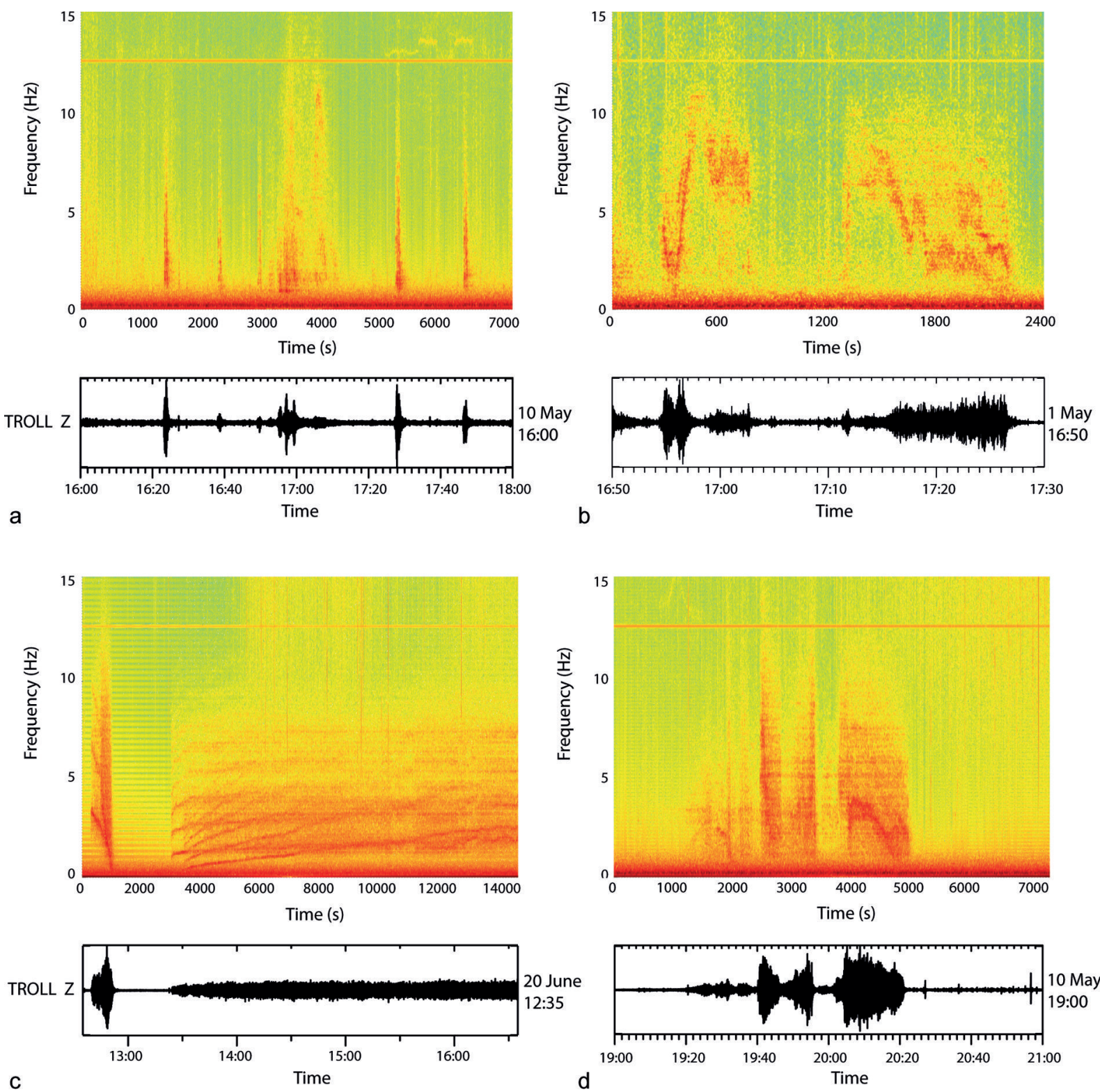

Fig. 2. Waveform (bandpass-filtered between 1 and $8 \mathrm{~Hz}$; bottom part of each panel) and corresponding spectrogram (raw data; upper part) examples of iceberg signals. All are recorded on the vertical $(Z)$ component of station TROLL. The spectrograms are shown truncated at $15 \mathrm{~Hz}$ to enhance the visibility of the discussed characteristics. Date in 2012 is indicated; time is UTC. (a) A class 1 signal (16:54-17:10) associated with iceberg B15X, together with icequakes (at 16:24, 16:38, 17:28 and 17:46). (b) Class 2 signals associated with B15X, exhibiting opposite dispersion patterns. (c) Strong class 2 signal (12:36) with clear P-and S-wave arrivals and frequency gliding, and iceberg harmonic tremor (class 3, starting at 13:23), both associated with B15G. (d) A class 4 signal (19:20-20:22) associated with B15G_a, with both unstructured (e.g. 19:48-19:56) and structured (e.g. 20:04-20:22) segments.

analysis (Kværna and Ringdal, 1986). The station-source distance is derived from $\mathrm{S}-\mathrm{P}$-wave travel-time differences, whenever these seismic phases are identified and their onsets can be picked accurately. Whenever possible, multiple-station (i.e. three or more) observations are combined to produce a more accurate solution. In these cases, the seismic event location algorithm HYPOSAT is used (Schweitzer, 2001), with the standard global velocity model AK135 (Kennett and others, 1995). However, multiple-station location was possible only in $5 \%$ of cases due to problems involving (1) the large distances between the DML network stations, (2) the large distances between stations and iceberg positions, (3) the typically small amplitudes and emergent characters of the first onsets of the iceberg-related signals, (4) the lack of S-phases for signals with sources farther off the coast, and (5) data availability. In most cases, signal-source locations are only based on backazimuth results at TROLL and SNAA, in combination with the $\mathrm{S}-\mathrm{P}$ travel-time differences when available. In several cases, we obtained only very approximate estimates based solely on TROLL data.

After determining the source location, we try to associate the signal with a known iceberg position. Daily iceberg positions are reported in the BYU database (Long and others, 2002; Stuart and Long, 2011a,b). To increase the temporal resolution, and to obtain information on the proximity of the icebergs to the ice shelf, we also used NIC tracking information and Moderate Resolution Imaging Spectroradiometer (MODIS) satellite imagery. In doing so, we could gain details of their trajectory (e.g. rotations), and information on changes to their shape and size, that might help us to identify possible collisions or calving. The NIC 


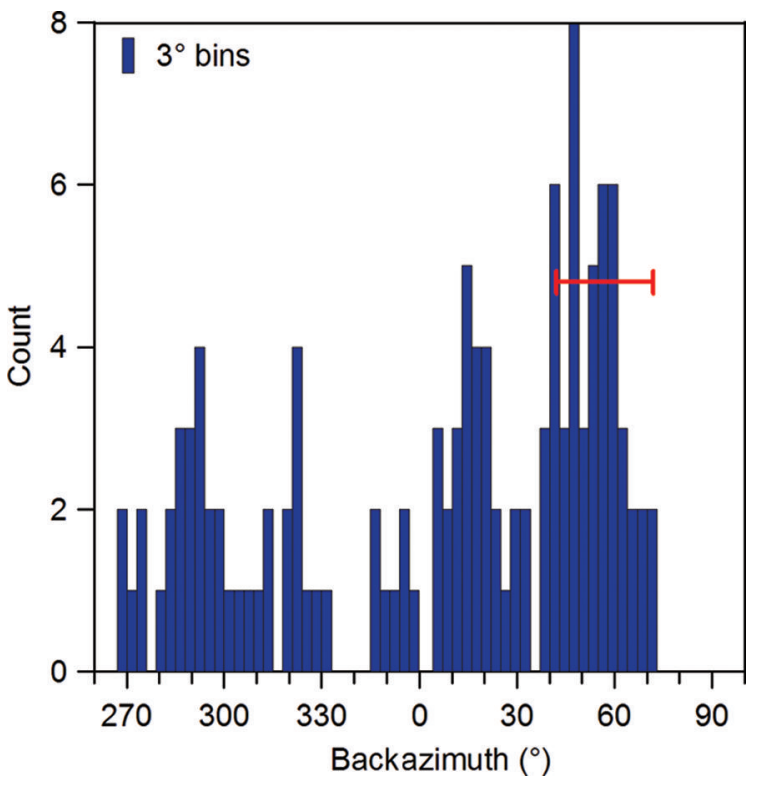

Fig. 3. The 121 reliable backazimuth estimates at TROLL in $3^{\circ}$ bins. The red bar marks the general $\pm 15^{\circ}$ uncertainty of the backazimuth estimates.

code names (see Appendix) are used for tracked icebergs considered in this study.

To obtain an indirect estimate of keel depth for the observed icebergs, their freeboard heights were measured. The vertical dimension can be estimated by matching up the iceberg trajectories with anomalously high surface-elevation measurements from satellite altimetry. We used CryoSat-2 data from the interferometric synthetic aperture radar (InSAR) mode (Wingham and others, 2006) and picked point observations that were elevated by $>20 \mathrm{~m}$ over the surrounding ocean or sea-ice surface, within a search limit of $10 \mathrm{~km}$ and 10 days from the location and timing of the iceberg trajectories.

\section{RESULTS AND DISCUSSION}

\subsection{The seismic signals}

About 200 signals related to drifting icebergs were observed at TROLL. Their duration varies significantly, from $<2$ min to $\sim 1$ day, most of them lasting $<30 \mathrm{~min}$. The signals have a typical frequency range of $\sim 0.7-12 \mathrm{~Hz}$. Their spectrograms display variable yet distinctive structural characteristics, including dominant frequency bands that may exhibit frequency gliding, and bands organized in sets of welldeveloped harmonics (iceberg harmonic tremor, IHT) (e.g. MacAyeal and others, 2008a). Others can be so unstructured that they appear almost chaotic. The vast majority of structured signals are characterized by the existence of a background, unstructured mesh of energy, also observed in other studies (e.g. Jansen, 2008). In most cases, the first onset of the signal is very difficult to distinguish from background noise. Very few instances of signals with welldefined P- and S-phases have been observed; they tend to exhibit a long sequence of highly dispersed energy after the S-wave arrival. Even in such cases, the signals show characteristic dispersion patterns that differ from those of earthquakes and icequakes. To help organize the icebergrelated signals, the following, phenomenological classification was developed.
We defined five classes (examples shown in Fig. 2):

Class 1: signals that are mostly unstructured (e.g. 16:54 to $17: 10$ in Fig. $2 a$ ).

Class 2: structured signals, typically with one dominant frequency band and sometimes a few repetitions, exhibiting frequency gliding. The dispersion pattern usually trends from low to high frequencies, but the opposite trend is also observed. See Figure $2 \mathrm{~b}, 16: 54-$ 17:03 for low-to-high, and 17:12-17:27 for high-to-low frequency gliding.

Class 3: IHT, in which one or several harmonics that may or may not exhibit frequency gliding are present, with durations varying from a few minutes to almost a day. See Figure 2c, from 13:23 to the end of the sequence.

Class 4: composite signals that include two or more of the above patterns, in a way that is impossible to tell the constituting signals apart (see Fig. 2d).

Class 5: undefined signals that cannot be securely classified as any of the above since their characteristics are indiscernible. This is mainly attributed to very low signal-to-noise ratio (SNR) or disturbance by other, overlaying signals (e.g. earthquakes).

Our classification concept is very similar to, but less detailed than, that of Talandier and others (2006). They identified two different families of signals, one with prominent spectral lines and one with a much broader (whiter) spectrum, and subdivided these further into seven classes and three types, respectively. Our dataset exhibits less variability, in particular for unstructured signals, and can be adequately described by a smaller number of classes.

The sources of the observed signals are distributed in the coastal region between roughly $15^{\circ} \mathrm{E}$ and $8^{\circ} \mathrm{W}$. Concerning uncertainties, the backazimuth estimates are very sensitive to the SNR of the observed seismic data. To ascertain the validity of the results, we systematically removed from the dataset all signals that rendered only non-resolvable backazimuth estimates. This resulted in a dataset of 121 signals that, based on TROLL backazimuth only, appear distributed at angles ranging roughly from $270^{\circ}$ to $360^{\circ}$ and $0^{\circ}$ to $70^{\circ}$, with a mean uncertainty of about $\pm 15^{\circ}$ (Fig. 3).

The overall uncertainty of station-source distance estimates is the sum of observation errors (e.g. seismic phase picks), velocity model uncertainties, and ambiguity in seismic phase identification. In particular regarding the latter, the observed S-phases could be converted phases from hydroacoustic to seismic. Our ray-tracing calculations show that this may introduce a difference in the order of $\sim 1 \mathrm{~s}$ in the $\mathrm{S}-\mathrm{P}$ travel times, depending on ice- and waterlayer thickness. Such a time difference could add $\sim 10 \mathrm{~km}$ to the uncertainty of distance calculations, which is small with respect to the general location error-ellipses in this study (major semi-axes $\sim 50 \mathrm{~km}$ ).

\subsection{The observed icebergs}

The observed signals span a time interval during which four large, tabular icebergs had been drifting along the DML shoreline, roughly between $15^{\circ} \mathrm{E}$ and $8^{\circ} \mathrm{W}$. According to the NIC and BYU databases, three of them have code names B15X, B15G and B17A respectively. Although comparable in size with B15X, the fourth iceberg was not tracked by any agency. 


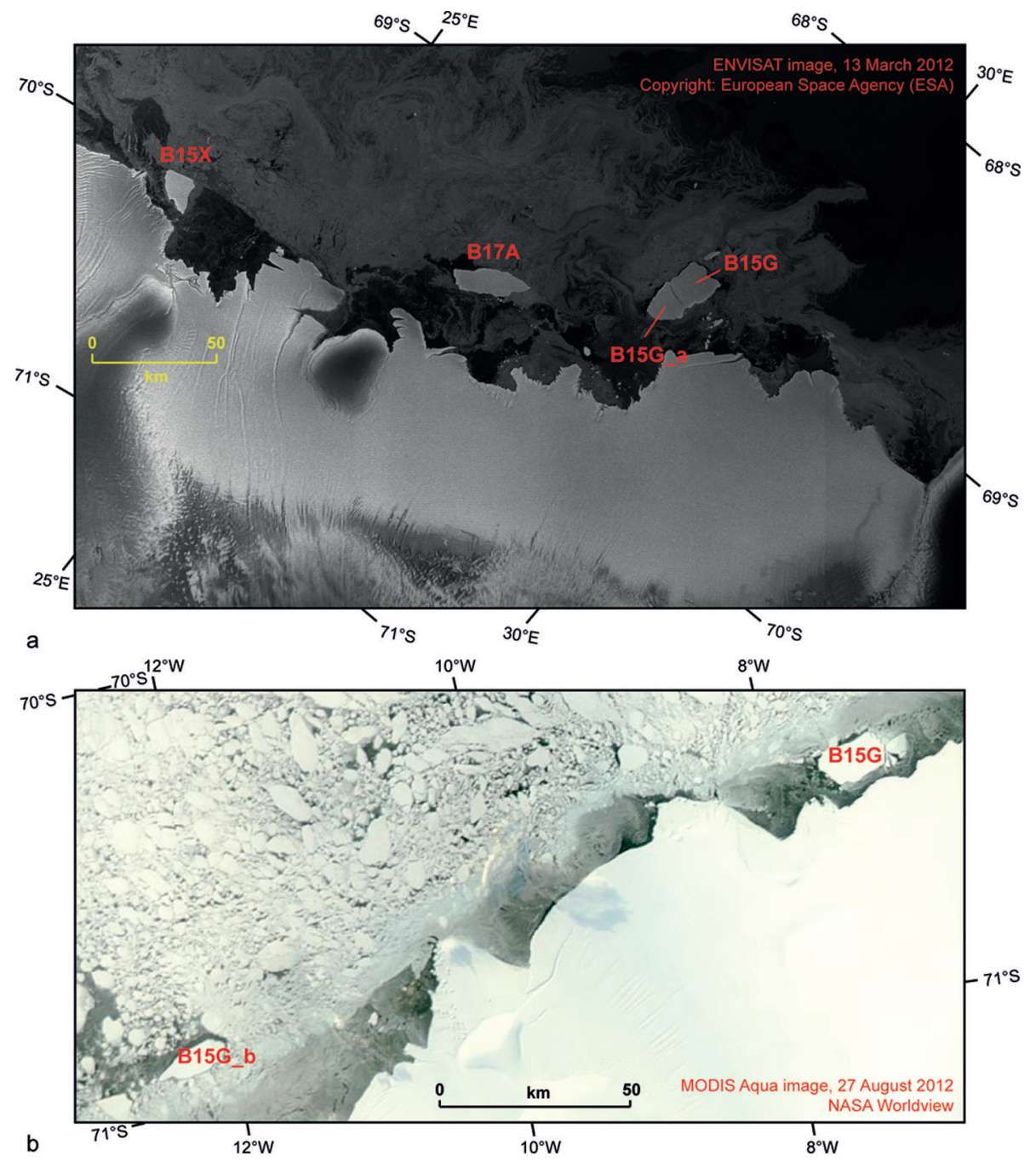

Fig. 4. Satellite images showing the icebergs discussed in this study. (a) Envisat Advanced Synthetic Aperture Radar (ASAR) image on 13 March 2012, showing icebergs B15X, B17A and B15G. The parent iceberg B15G can be seen calving into B15G and the untracked B15G_a. (b) MODIS Aqua mosaic for 27 August 2012, showing B15G with the last shape observed in this study and the fragment B15G_b.

The tracked icebergs we observe are fragments of two very large initial icebergs (B15 and B17). B15 calved off the eastern part of the Ross Ice Shelf on 21 March 2000 (e.g. Arrigo and others, 2002) and collided repeatedly with the ice shelf, causing the calving of B17 around 7 April 2000 (MacAyeal and others, 2008b). On 30 April 2001, near Cape Adare, fragment B15B calved, creating among others B15G (Martin and others, 2010 and auxiliary online material). Within this study, B15G was observed with two different geometries (Fig. 4a and b). Envisat imagery from day-of-year (DOY) 073 of year 2012 (13 March) shows clearly that the untracked, fourth iceberg has calved off the parent iceberg B15G. Thus, we hereafter refer to it as B15G_a (Fig. 4a). Since its trajectory is only poorly constrained, B15G_a and signals associated with it will not be discussed in great detail. Finally, B15G calved further into the shape observed last in this study and the also untracked fragment B15G_b (Fig. 4b) sometime between 30 April and 3 May 2012.

Regarding iceberg freeboard heights, the employed approach resulted in 10-50 independent elevation profiles across each iceberg, at various locations along the trajectories. The median freeboard heights of these observations were $47-49 \mathrm{~m}$ for each iceberg (Table 2), which translates into keel depths of $250-300 \mathrm{~m}$. Our results are obtained assuming a firn air content of $12-18 \mathrm{~m}$, which is typical along the coast of East Antarctica, according to a firn densification model forced with a regional climate model, and tuned to firn depth-density observations (Arthern and others, 2010; Lenaerts and others, 2012; Ligtenberg and others, 2014). Our keel depths are as large as those estimated for the same icebergs over a decade ago, when they calved off the Ross Ice Shelf (Dowdeswell and Bamber, 2007) or were drifting on the other side of the continent (Martin and others, 2010). This indicates a relatively high surface accumulation that has been able to compensate for both surface and basal melting (e.g. Jansen, 2008; Stephenson and others, 2011).

The observed icebergs moved westwards within the study region (Fig. 5a and b). The first icebergs to enter it were B15X and B15G_a in April 2012. Satellite images show that, while travelling along the Lazarev and Fimbul Ice Shelf coasts, they maintained almost a steady distance between them. They left the study area in June 2012. Meanwhile, in late May 2012, icebergs B15G and B17A approached the Lazarev Ice Shelf. At that time, B15G still had the shape shown in Figure 4a, but it calved into the shape observed last herein and B15G_b (Fig. 4b) sometime between 30 April and 3 May 2012. The two B15G fragments and B17A traveled close to each other from mid-May until the end of 


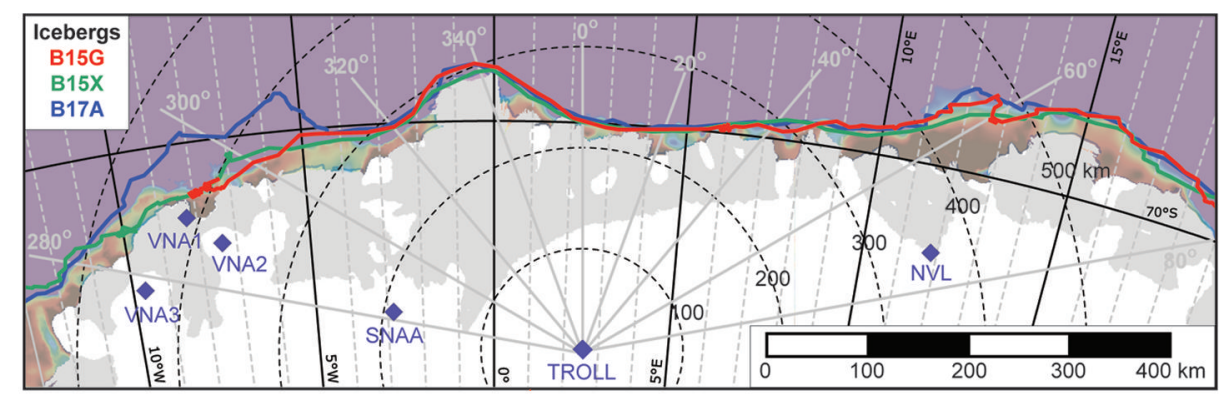

a
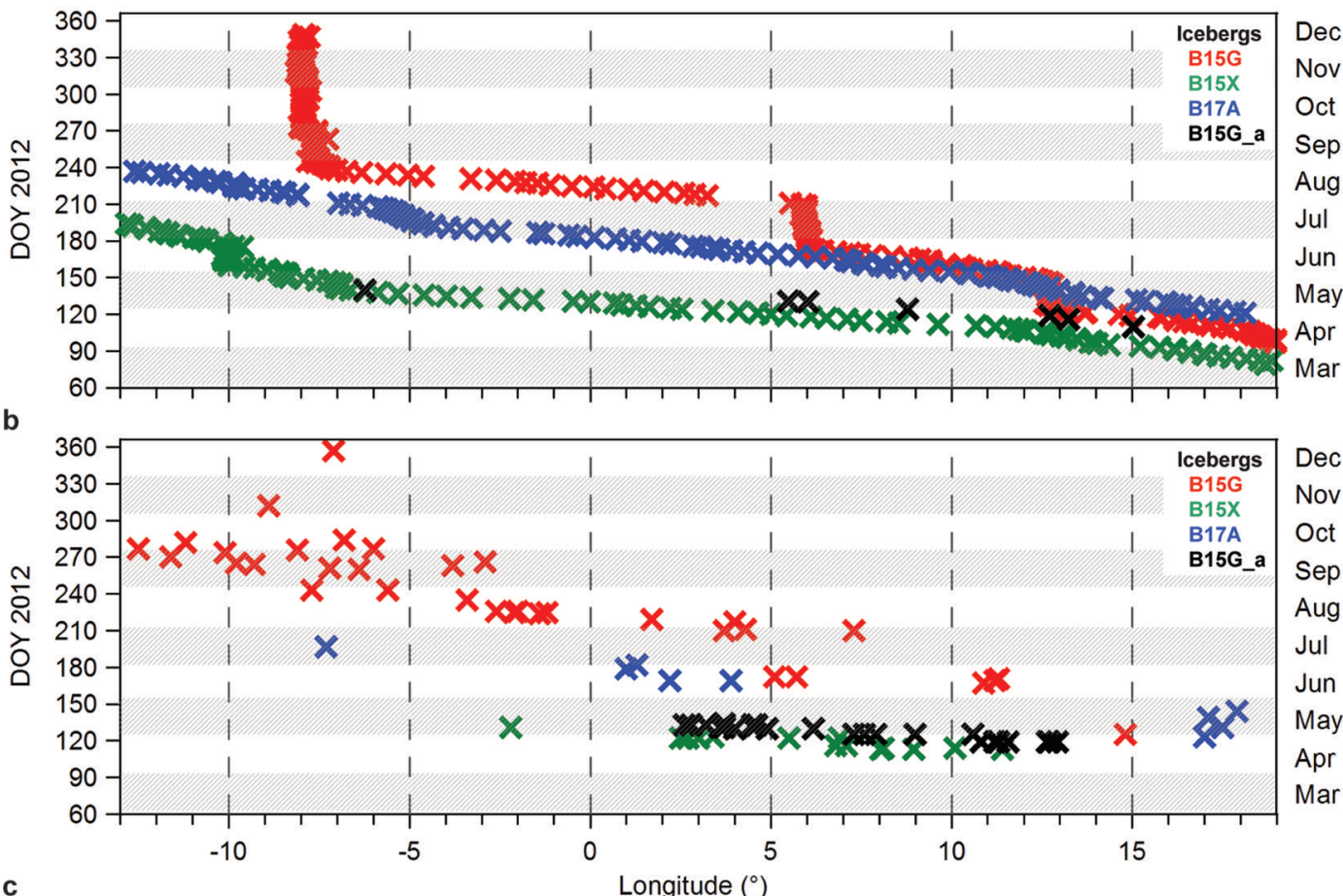

Fig. 5. Iceberg trajectories and spatio-temporal distribution of associated signals. (a) Similar to Figure 1, but including tracked iceberg trajectories, shown as colored curves. Bathymetry (Arndt and others, 2013) is shown using the same color scale as in Figure 1, but with increased transparency to enable the observation of the trajectories. (b) Longitude distribution with time for the three tracked icebergs, according to the BYU database of daily iceberg positions. Also shown are positions of untracked B15G_a, as obtained in this study based on satellite images. (c) Same as (b) for the seismic signal sources associated with the four observed icebergs. Only well-resolved and associated signals are shown.

June (between $13^{\circ}$ and $6^{\circ} \mathrm{E}$ longitude in Fig. 5b). B15G lingered around $6^{\circ} \mathrm{E}$ for about a month, while B17A and B15G_b proceeded westwards. By the time that B15G continued its drift, B17A had reached the western border of our observation region. B15G reached the Ekström Ice Shelf coast near VNA1 (Fig. 5a) in late August 2012 and became immobilized and fasted, holding that position until the end of our observation period in December 2012 (Fig. 5b).

Table 2. Characteristics of the observed icebergs

\begin{tabular}{|c|c|c|c|c|c|c|c|}
\hline Name & Freeboard height* & $\begin{array}{c}\text { Calving time } \\
\text { within study area }\end{array}$ & $\begin{array}{l}\text { Calving location } \\
\text { within study area }\end{array}$ & $\begin{array}{l}\text { Time entering } \\
\text { study }^{\text {area }}\end{array}$ & $\begin{array}{c}\text { Dimensions } \\
\text { upon entering } \\
\mathrm{km}^{2}\end{array}$ & 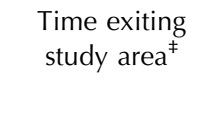 & $\begin{array}{c}\text { Dimensions } \\
\text { upon exiting } \\
\mathrm{km}^{2}\end{array}$ \\
\hline B15X & $48 \pm 8$ & - & - & 4 Apr 2012 & 169 & 29 May 2012 & 174 \\
\hline B15G & $49 \pm 3$ & 30 Apr-3 May 2012 & $69.35^{\circ} \mathrm{S}, 13.91^{\circ} \mathrm{E}$ & 28 Apr 2012 & 280 & fasted & 162 \\
\hline $\mathrm{B} 17 \mathrm{~A}$ & $49 \pm 2$ & - & - & 11 May 2012 & 320 & 9 Aug 2012 & 331 \\
\hline B15G_a & - & - & - & 17 Apr $2012^{+}$ & 185 & May/June $2012^{\dagger}$ & - \\
\hline B15G_b & - & - & - & 30 Apr-3 May 2012 & $\sim 118^{\circledR}$ & August $2012^{+}$ & $\sim 118$ \\
\hline
\end{tabular}

*Median and interquartile range of CryoSat-2 elevations.

${ }^{\dagger}$ Information from satellite imagery.

${ }^{\ddagger}$ Taken from BYU Antarctic iceberg-tracking database. In the case of uncertain time, averaged coordinates over the corresponding time interval are reported. ${ }^{\S}$ From NIC (http://www.natice.noaa.gov/ps/javascriptproductviewer/index.html).

${ }^{\top}$ Approximate information based on B15G earlier and final dimensions. 


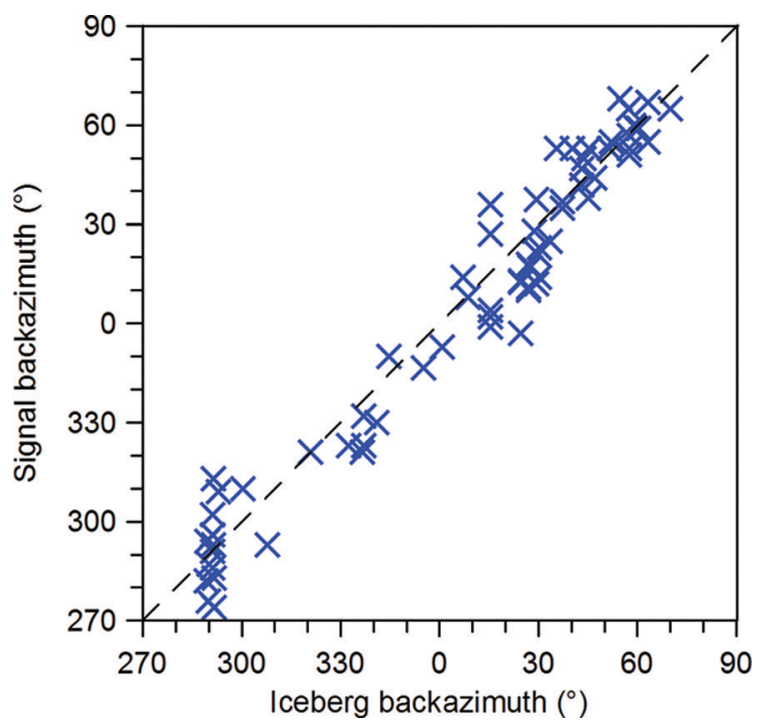

Fig. 6. Correlation between BYU database iceberg-location backazimuth and backazimuth estimates obtained from seismic signals observed at TROLL.

Based on the BYU database daily iceberg positions, the iceberg drift rates vary widely. For example, iceberg B15X took only 8 days to drift from $10^{\circ}$ to $5^{\circ} \mathrm{E}$, whereas iceberg B15G took 51 days. Such slow transit times are typically observed when icebergs become stuck. B15G shows a greater such tendency than the other icebergs, remaining stationary at two places along the coast, near $6^{\circ} \mathrm{E}$ and $8^{\circ} \mathrm{W}$. In contrast, B17A keeps a more even drift speed (Fig. 5b), leaving the Fimbul coast relatively fast, then adopting a more seaward trajectory from $\sim 4^{\circ} \mathrm{W}$ onwards (blue line in Fig. 5a). As expected, stationary locations are concentrated in shallow waters (water depth $<500 \mathrm{~m}$ ) and at the ice-shelf front (e.g. B15G at $\sim 6^{\circ} \mathrm{E}$ ). In a few cases, however, iceberg drift slowed down in deep-water $(>1000 \mathrm{~m}$ depth) regions (e.g. B15G at $\sim 14^{\circ} \mathrm{E}$ and $7^{\circ} \mathrm{W} ; \mathrm{B} 17 \mathrm{~A}$ at $\sim 6^{\circ} \mathrm{W}$ ). This may be related to the existence of eddies or sea-ice distribution, as inferred from iceberg rotations captured on satellite images.

\subsection{Signal association with icebergs}

Although the total number of presumed iceberg-related signals recorded at TROLL within this study is close to 200, we obtained reliable backazimuth estimates for only 121 . Travel-time based, multiple-station source location was possible only for nine, mainly due to the difficulty in measuring accurately the first onsets of the waveforms. Thus, in the overwhelming majority of cases, the source estimate is based predominantly on backazimuth estimates at TROLL and SNAA, while single TROLL estimates are also common. These source location estimates have large uncertainties, with error ellipse major semi-axes exceeding $50 \mathrm{~km}$. This means that it is impossible to discriminate between icebergs that travel closer together (Fig. 5b) than the major axis of the error ellipse. To avoid iceberg and signal erroneous associations, all ambiguous cases were removed from the dataset, reducing the number of signals to 84. All removed signals could be associated with more than one of the drifting icebergs discussed herein. We cannot exclude that smaller calving events from the DML ice shelves may also have occurred during the study period, and there are numerous smaller, local icebergs near the ice-shelf
Table 3. Overview of the seismic signals associated with icebergs

\begin{tabular}{|c|c|c|c|c|c|}
\hline Iceberg & $\begin{array}{l}\text { Number } \\
\text { of signals }\end{array}$ & $\begin{array}{c}\text { First } \\
\text { signal date }\end{array}$ & $\begin{array}{l}\text { Location } \\
\text { on first } \\
\text { signal date* }\end{array}$ & $\begin{array}{l}\text { Last } \\
\text { signal date }\end{array}$ & $\begin{array}{c}\text { Location } \\
\text { on last } \\
\text { signal date* }\end{array}$ \\
\hline B15X & 14 & 22 Apr 2012 & $\begin{array}{c}69.85^{\circ} \mathrm{S} \\
8.54^{\circ} \mathrm{E}\end{array}$ & 10 May 2012 & $\begin{array}{l}69.57^{\circ} \mathrm{S} \\
0.48^{\circ} \mathrm{W}\end{array}$ \\
\hline B15G & 35 & 4 May 2012 & $\begin{array}{l}69.51^{\circ} \mathrm{S} \\
12.90^{\circ} \mathrm{E}\end{array}$ & 22 Dec 2012 & $\begin{array}{l}70.45^{\circ} \mathrm{S} \\
7.83^{\circ} \mathrm{W}\end{array}$ \\
\hline B17A & 10 & 2 May 2012 & $\begin{array}{l}69.48^{\circ} \mathrm{S} \\
17.41^{\circ} \mathrm{E}\end{array}$ & 15 Jul 2012 & $\begin{array}{c}69.88^{\circ} \mathrm{S} \\
4.70^{\circ} \mathrm{W}\end{array}$ \\
\hline B15G_a & 27 & 28 Apr 2012 & $\begin{array}{l}69.43^{\circ} \mathrm{S} \\
12.72^{\circ} \mathrm{E}^{+}\end{array}$ & 13 May 2012 & $\begin{array}{c}70.00^{\circ} \mathrm{S} \\
3.70^{\circ} \mathrm{E}^{\neq}\end{array}$ \\
\hline
\end{tabular}

*From BYU database.

${ }^{\dagger}$ From satellite imagery.

${ }^{\ddagger}$ From seismological data analysis.

fronts from previous calving events. However, the lack of signals that are unaccounted for indicates that potential seismic events from these smaller icebergs are within the noise level.

Figure 5c shows the longitude of the 84 iceberg-associated signals against time. These longitude values are those estimated with the use of seismological data. A total of 27 signals could be attributed to iceberg B15G_a, based on its position on MODIS satellite imagery (Fig. 5b). The geographic spread of the seismological source locations is obvious (e.g. observe the scatter of the red symbols after DOY 240). However, an association was possible due to the lack of other possible sources. The scarcity of such associations for the longitude leg $5-10^{\circ} \mathrm{E}$, where B15G and B17A drift in close proximity, reflects the limitations of the current monitoring possibilities. Despite these limitations, more than half the recorded signals rendered a reliable backazimuth estimate, and more than one-third could be associated with a particular iceberg.

For the signals associated with tracked icebergs, the relationship between estimated backazimuth values from TROLL data (signal backazimuth) and that corresponding to iceberg positions in the BYU database (iceberg backazimuth) is presented in Figure 6 . The distribution reflects the general backazimuth uncertainty level, as exhibited by the large signal concentration around $290^{\circ}$, associated with the fasting of iceberg B15G near the Neumayer III station.

The spatial distribution of the associated iceberg signals is summarized in Figure 7 . The spatial extent of this dataset spreads over the DML shore, between the Lazarev Ice Shelf to the east and the Ekström Ice Shelf to the west, corresponding roughly to a $400 \mathrm{~km}$ radius from TROLL. Table 3 provides an overview of the number of associated signals per iceberg, with first and last observation date and location. Initially, in April 2012, observed signals were emitted only by iceberg B15X and the untracked B15G_a. However, as soon as icebergs B15G and B17A approached the Lazarev Ice Shelf (late May), signals were also recorded from them (Table 3). The largest number of signals came from iceberg B15G, and the second largest from B15G_a. Icebergs B15X and B17A apparently produced fewer detectable signals. B15G generally drifted more slowly and lingered in certain areas for a longer time than the other three icebergs, implying an increased potential for seismic emission production, probably due to more frequent interaction with its surroundings. However, this behavior was 


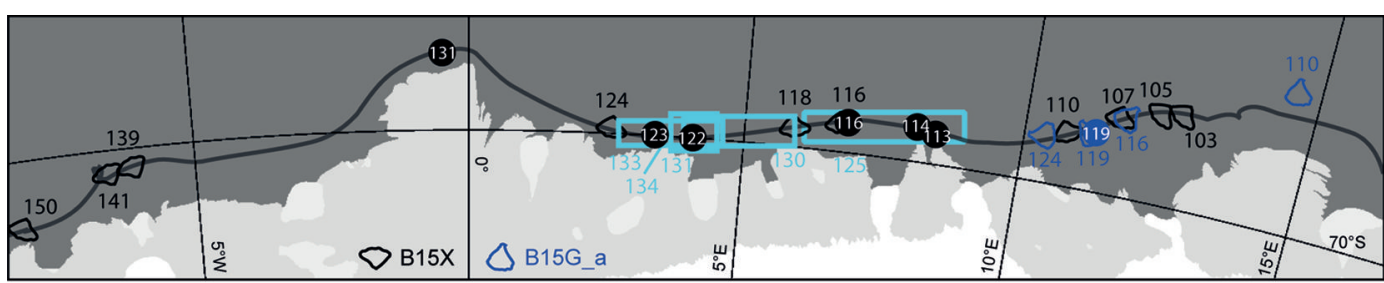

a

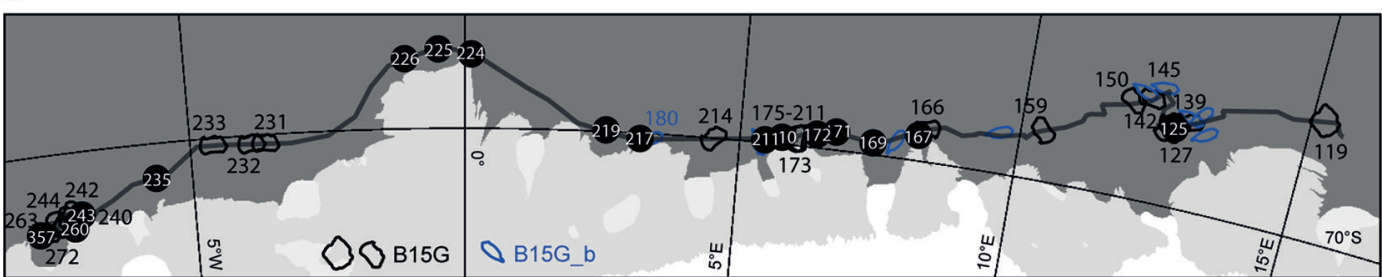

b

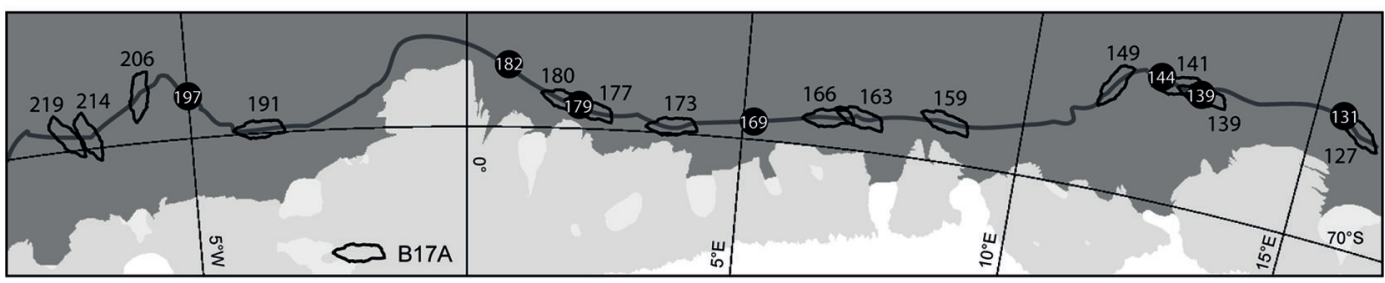

Fig. 7. Iceberg positions and orientations, based on satellite images (black and blue iceberg outlines), with number denoting DOY 2012 Icebergs are shown to scale. Filled circles denote iceberg positions for which iceberg-signal associations were resolved. Note that several dates include more than one of the 84 associated signals. Iceberg positions and iceberg trajectories (grey line) are taken from the BYU database. (a) Course and signals of B15X (black) and the untracked B15G_a (blue; from MODIS images). B15G_a signal location regions, based only on seismological data, are enclosed in cyan rectangles. (b) Same as (a), but for B15G (black) and B15G_b (blue; from satellite images). (c) Same as (a), but for B17A

not observed for B15G_a, whose relation to B15G may imply similar signal production (e.g. owing to the existence of favorably oriented structures within their volumes). We do not have adequate indications that B15G_b may be associated with any of the signals, so we do not analyze this possibility further.

\subsection{Signal occurrence and characteristics against environmental variables}

The seismic signals within our dataset are observed both for iceberg positions very close to the edge of the ice shelf, where icebergs could collide with the shelf or scrape on shallow bathymetric features, and at offshore, deeper positions, where the icebergs are more likely to be drifting freely (Fig. 7). However, except for B17A, the icebergs seem to produce most of their signals in the coastal area, between $7^{\circ}$ and $2^{\circ} \mathrm{E}$. Good examples are the signals associated with B15G resuming its drift after lagging at $\sim 6^{\circ} \mathrm{E}$, between 23 June and 29 July 2012. Seismic signals were observed on 28 and 29 July (DOY 210, 211 in Fig. 7b), just before it started to drift again. From wind-vector data (European Centre for Medium-Range Weather Forecasts, http://apps. ecmwf.int/datasets/data/interim_full_daily/), it seems probable that the iceberg became free due to a storm hitting the area between midday on 27 July and the evening of 28 July. However, we do not know whether the signals are the result of the iceberg colliding repeatedly with the ice shelf or scraping against a bathymetric feature. Since the water is assumed to be $>1000 \mathrm{~m}$ deep in that area (Arndt and others, 2013), the latter is unlikely.

During the drift of the icebergs along the study area, only one calving event was documented (Table 2). This was the calving of B15G_b from B15G off the Lazarev Ice Shelf. No seismic signals from this event were detected.

A phenomenological signal classification scheme was introduced in Section 2. Different aspects of it are presented in Figure 8. Figure 8a shows the geographic distribution of signals per class. Two general observations can be made: (i) most signals belong to class 1 , and (ii) class 1 signals are observed both close to the edge of the ice shelf and in more seaward positions.

The histogram of Figure $8 \mathrm{~b}$ shows the distribution of the 84 signals per class per iceberg. Class 1 signals are present for all icebergs, but otherwise the representation of classes per iceberg varies. An interesting observation is that, while other icebergs exhibit a variety of signals, B17A seems to be associated only with class 1 signals. All fragments of B15 produced class 2 signals. However, class 3 (IHT) is observed only for B15G and B15G_a, which are fragments of the same parent iceberg. With the information at our disposal, we cannot conclude whether this is an indication of a 'genetic predisposition' to emit IHT.

Earlier studies have presented signals from other fragments of iceberg B15. For example, B15B appeared in Talandier and others $(2002,2006)$ and Martin and others (2010), the latter showing several examples of spectrograms from another fragment, B15A. Talandier and others (2002) present hydroacoustic and seismic records and spectrograms from signals associated with B15B that would belong to our class 2. However, their signals lack energy at frequencies below $2 \mathrm{~Hz}$, due to the known high-pass filter effect of the sound channel in the ocean (Talandier and others, 2002), whereas our signals, with lower frequencies around $0.7 \mathrm{~Hz}$, originated closer to the coast and were not 


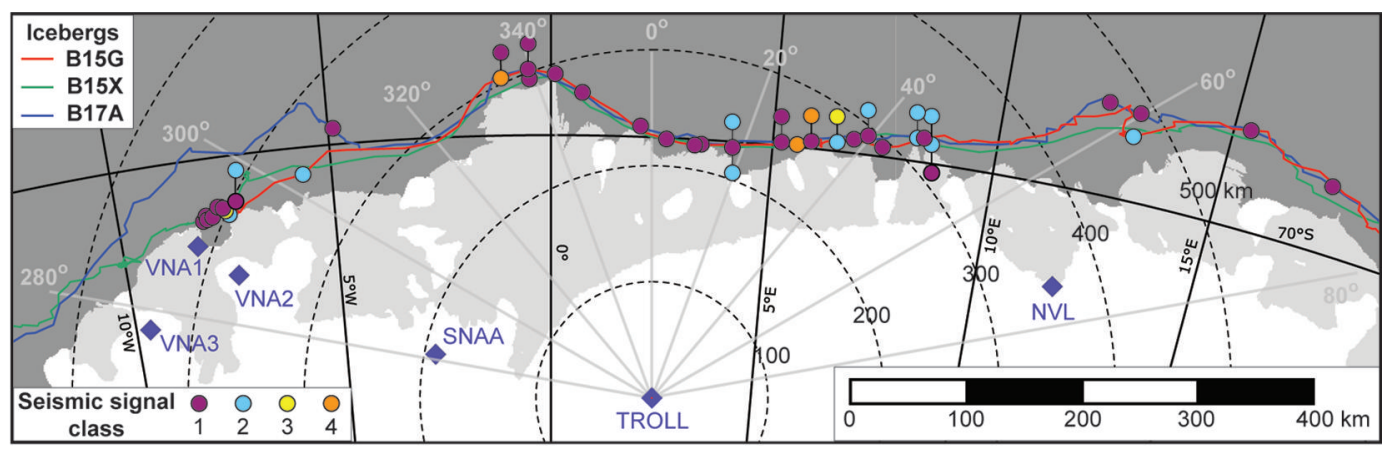

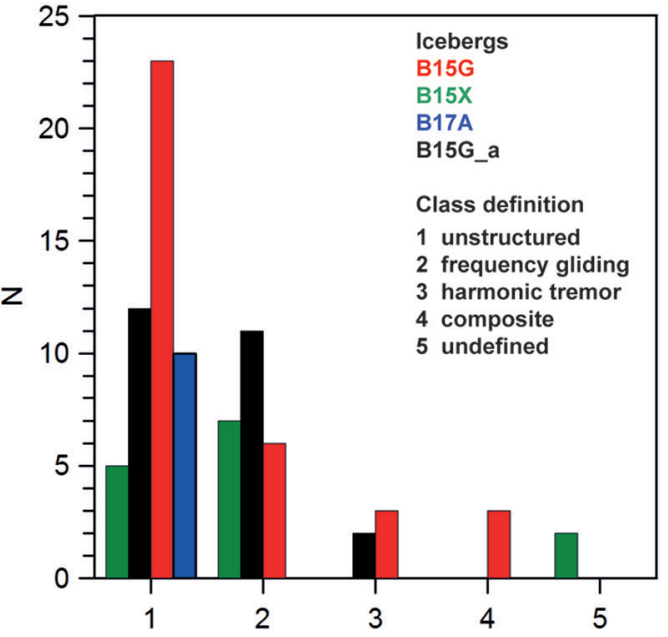

Signal class based on spectrogram characteristics

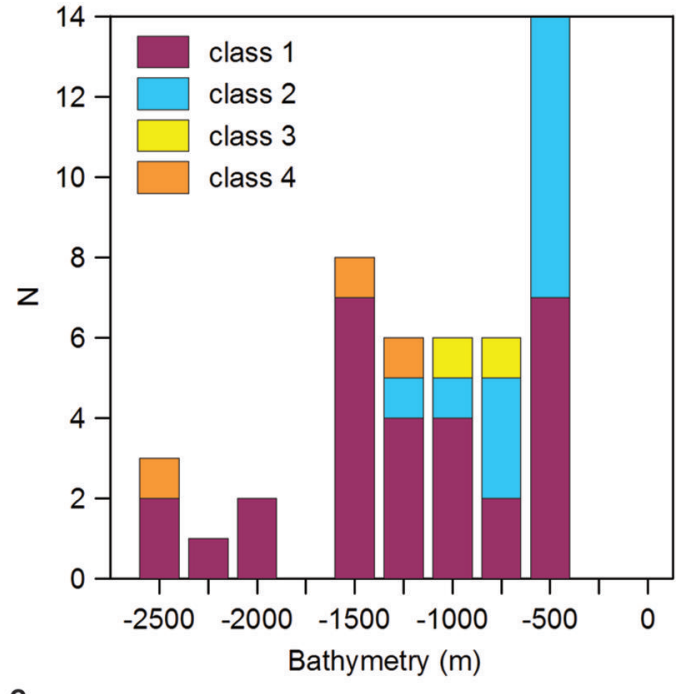

Fig. 8. Various aspects of the iceberg-signal classes. (a) Similar to Figure 1, but showing the geographic distribution of the four defined signal classes (colored circles). Multiple signal occurrences on the same day are grouped using vertically stacked symbols. Note that the multitude of signals associated with the fasting of B15G near VNA1 cannot be depicted faithfully, due to the scale of the map. The iceberg trajectories (colored lines) are based on the BYU database. (b) Histogram of the number of signals per class per iceberg. (c) Number of signals per class versus water depth. Signals that could not be classified (class 5) are not included. Note that only the three tracked icebergs (B15X, B15G and B17A) are included, for positions with measured (not interpolated) bathymetry (Arndt and others, 2013), so the number of observations in this histogram equals neither the total number of signals in our dataset nor the histogram count in (b).

affected by the sound channel. Signals associated by Martin and others (2010) with B15A, and recorded at seismic stations in Antarctica, are much more similar to our class 3 signals, in particular when recorded at a comparable distance (Martin and others, 2010, fig. 11). A variety of signals, very similar to those we observe, was also recorded by Müller and others (2005, supporting online material) and Jansen (2008), and attributed to iceberg B9A and icebergs A38B and A43G, respectively. This comparison suggests that it is very difficult to identify signature characteristics in the signals for particular icebergs.

It remains an open question to what extent the mechanisms behind these classes are governed by characteristics of the involved icebergs (dimensions, keel depth, the existence of crevasses), their trajectories (e.g. bathymetric features, proximity to the ice shelf and other icebergs, sea-ice coverage), ocean state (tides, currents) and weather conditions (wind).

The correlation of the different signal classes with bathymetry is shown in Figure 8c. The distribution confirms that the occurrence of class 1 signals is independent of bathymetry, whereas the more structured class 2 and 3 signals are mostly observed in shallower waters. These trends are in general accordance with the findings of Talandier and others (2006), who observe the majority of whiter spectrum signals (class 1 in this study) from sources on the high seas, whereas signals with clear eigenfrequencies (classes 2 and 3 in this study) have their sources near the coastline, noting, however, that there exist exceptions. It is unclear how the wide distribution of class 1 signals in this study can be interpreted. We did not find any clear correlation with any parameter (e.g. signal-source size, source-station distance) that might hint at a probable source process. The same iceberg can produce both class 1 and structured signals at nearby locations (see, e.g., grouped class 1 and 2 occurrences in Fig. 8a), suggesting that observation distance cannot have a decisive effect in this distribution. Regarding bathymetry, the few cases of structured signals in deep-water locations are observed for stationary icebergs (e.g. B15G at $\sim 6^{\circ} \mathrm{E}$ ), and therefore cannot be solely interpreted by bathymetric conditions. Unfortunately, we have relatively poor resolution of the bathymetry in the area, and only indirect information on iceberg keel depths. The steep bathymetric gradients near the ice shelf, as in the area around $6^{\circ} \mathrm{E}$, also need to be taken in account. Keel depths of grounded icebergs can be a proxy for bathymetry; this is currently under investigation in a separate study and is not discussed further herein. It is difficult to investigate and interpret safely the mechanisms behind the generation of the signals in the absence of detailed information regarding the surroundings of the icebergs at 
the time of their emission. The most conclusive studies so far in this respect benefit from combined favorable seismic observation conditions, and good control of the involved iceberg's position and resulting geometrical relations to its surroundings (e.g. MacAyeal and others, 2008a; Martin and others, 2010; Dziak and others, 2013). Well-constrained cases from this study will be presented in greater detail and interpreted in work that is currently in preparation.

\subsection{Implications for iceberg monitoring}

In a similar study, Müller and others (2005) tracked one iceberg (B9A) as it drifted along the DML coast, using seismological data of any station of the regional network at DML available for each signal. In this study, we track the drift of four icebergs over three-quarters of a year. We consequently start from the single TROLL backazimuth estimate and add information where available, thus assessing tracking capabilities at regional distances from seismic stations.

Although TROLL is relatively far from the coast, its central position allows monitoring of the entire length of the coastline between $8^{\circ} \mathrm{W}$ and $15^{\circ} \mathrm{E}$, with an average observation radius of $400 \mathrm{~km}$. This position offers a better azimuthal sensitivity for sources along the DML coast than the locations of the stations closer to the shoreline (Fig. 1). In Müller and others (2005), signals from iceberg B9A were spread over the region between $25^{\circ} \mathrm{W}$ and $5^{\circ} \mathrm{E}$, with a maximum observation range of $\sim 680 \mathrm{~km}$. For several of the source-location estimates in that study, the seismic array at Neumayer III had been used, offering an SNR improvement by a factor equal to the square root of the number of array elements (e.g. Schweitzer and others, 2012). In comparison, the performance of the single seismic station, TROLL is remarkable, demonstrating the potential of high-quality, single stations even at large distances.

The information from satellite remote sensing in Figure 7 about iceberg positions and orientations provides an overview of the availability of satellite imagery for the area of interest during the study. The observed icebergs drifted within the limits of the study region at the beginning of the dark season, and most of them were on their way out when the light returned. Cloud coverage and the lack of cloudpenetrating microwave satellite imagery further reduced tracking capabilities using satellite images. The daily iceberg positions (BYU) are invaluable, but do not provide insight into additional aspects of their drift (e.g. orientations); moreover, the database provides only restricted real-time potential (see Appendix). In addition, as the case of B15G_a demonstrates, not all large, tabular icebergs are being tracked. This increases the value of seismological observations, in particular for real-time data transmitting stations, which can be used to supplement satellite information and tracking databases.

\section{SUMMARY AND CONCLUDING REMARKS}

We analyzed $\sim 200$ seismic signals, recorded by seismic station TROLL in DML during April-December 2012, which could be associated with the drift of large, tabular icebergs over a range of $23^{\circ}$ of longitude.

Potential non-iceberg sources including earthquakes, icequakes, hydroacoustic sources and environmental noise were first eliminated by examining the spectral properties of the signals. The location of the signal sources was estimated, using all available regional seismological resources, and found to be off the edge of the ice shelf. The signal sources moved westward, consistent with iceberg drift in the region.

During the same time, three tracked and one untracked tabular icebergs were observed drifting along the study area. Going back in time, we identified the untracked iceberg as a fragment of iceberg B15G. Iceberg freeboard heights were measured by satellite altimetry, providing indirect estimates of keel depths.

The association of the seismic signals with particular icebergs was achieved by comparing seismological results with iceberg positions. More than $30 \%$ of the starting dataset was associated with one particular iceberg, resulting in 84 signals distributed between $15^{\circ} \mathrm{E}$ and $8^{\circ} \mathrm{W}$. This is the largest such dataset ever to have been considered within a single study, combining a long interval of observation, along an extensive part of the coastline, with a multitude of seismic emissions from several icebergs. The resulting geographic distribution corresponds to an observation radius of $\sim 400 \mathrm{~km}$ from TROLL, demonstrating the potential of high-quality, regional seismic stations for monitoring large iceberg drift along the nearby coastline.

We classified the seismic signals into five classes, according to their spectral characteristics. This classification does not provide insight into signal generation processes. Signal classes are represented differently for the four icebergs. However, observed IHT (class 3 signal) cases are limited to two fragments of the same parent iceberg (B15G and B15G_a). Currently, the data at our disposal lack resolution to explore this observation further. The occurrence of the different classes varies, with those exhibiting highly structured frequency characteristics being scarcer than simpler individual signals. Future work needs to focus on interpreting the physical processes behind the different spectral characteristics of the observed signals. For this purpose, the physical conditions of the icebergs and their surroundings at the time of signal generation must be known in more detail.

Iceberg tracking conducted by satellite-based scatterometer backscatter analysis, although invaluable, cannot provide additional information crucial to interpret the mechanisms behind signal generation. Regarding satellite images, their availability can be rather sparse, particularly during the austral winter. Although the location accuracy with the seismic network in DML is currently limited, the seismological information can supplement the existing remote-sensing data to achieve a more complete drift history of the involved icebergs. This becomes even more important in the case of untracked icebergs.

\section{ACKNOWLEDGEMENTS}

The seismic station TROLL was installed by NORSAR with funding from the Norwegian Antarctic Research Expedition 2011-14 program. We are grateful for the support given by the Troll Station staff to keep the station in operation. Data from the GEOFON/Comprehensive Test Ban Treaty Organization (CTBTO) auxiliary seismic station SNAA at SANAE IV were retrieved from GeoForschungsZentrum (GFZ), Potsdam, Germany. Data from stations VNA1, VNA2 and VNA3 belonging to the seismic network of Neumayer III were retrieved from the WebDc EIDA portal (http://webdc.eu). Data from the Russian station NVL at Novolazarevskaya were kindly provided by Oleg Starovoit at the Geophysical Service of the Russian Academy of Sciences. A great wealth of satellite-based information and associated products was used 
in this study, both to support our background knowledge about the behavior of the observed icebergs and for figure compilation: MODIS Antarctica mosaic images, Envisat images, CryoSat-2 data, NIC Antarctic iceberg information, and the BYU Antarctic icebergs daily positions database. We thank Max König (Norwegian Polar Institute) for pointing out sources and repositories of satellite images. Wind-vector data, in original form as $U$ and $V$ wind component data, were obtained from the web portal (http://apps.ecmwf.int/datasets/ data/interim_full_daily/) of the European Centre for MediumRange Weather Forecasts. Maps in this paper were made with Quantarctica (www.quantarctica.org). Part of this work was conducted during M.P.'s employment with NORSAR. The manuscript benefited from the constructive comments and suggestions of two anonymous reviewers.

\section{REFERENCES}

Aoki S (2003) Seasonal and spatial variations of iceberg drift off Dronning Maud Land, Antarctica, detected by satellite scatterometers. J. Oceanogr., 59, 629-635

Arndt JE and 15 others (2013) The International Bathymetric Chart of the Southern Ocean (IBCSO) Version 1.0: a new bathymetric compilation covering circum-Antarctic waters. Geophys. Res. Lett., 40(12), 3111-3117 (doi: 10.1002/grl.50413)

Arrigo KR, Van Dijken GL, Ainley DG, Fahnestock MA and Markus T (2002) Ecological impact of a large Antarctic iceberg. Geophys. Res. Lett., 29(7), 8-1-8-4 (doi: 10.1029/2001GL014160)

Arthern RJ, Vaughan DG, Rankin AM, Mulvaney R and Thomas ER (2010) In situ measurements of Antarctic snow compaction compared with predictions of models. J. Geophys. Res., 115(F3), F03011 (doi: 10.1029/2009JF001306)

Ballantyne J (2002) A multidecadal study of the number of Antarctic icebergs using scatterometer data. Brigham Young University, Provo, UT

Chapp E, Bohnenstiehl DR and Tolstoy M (2005) Sound-channel observations of ice-generated tremor in the Indian Ocean. Geochem. Geophys. Geosyst., 6(6), Q06003 (doi: 10.1029/ 2004GC000889)

Dowdeswell JA and Bamber JL (2007) Keel depths of modern Antarctic icebergs and implications for sea-floor scouring in the geological record. Mar. Geol., 243, 120-131 (doi: 10.1016/j. margeo.2007.04.008)

Dziak RP, Park M, Lee WS, Matsumoto $\mathrm{H}$, Bohnenstiehl DR and Haxel JH (2010) Tectonomagmatic activity and ice dynamics in the Bransfield Straight back-arc basin, Antarctica. J. Geophys. Res., 115(B1), B01102 (doi: 10.1029/2009JB006295)

Dziak RP and 6 others (2013) Life and death sounds of Iceberg A53a. Oceanography, 26(2), 10-12 (doi: 10.5670/oceanog.2013.20)

Evers LG, Green DN, Young NW and Snellen M (2013) Remote hydroacoustic sensing of large icebergs in the southern Indian Ocean: implications for iceberg monitoring. Geophys. Res. Lett., 40, 4694-4699 (doi: 10.1002/grl.50914)

Fretwell P and 59 others (2013) Bedmap2: improved ice bed, surface and thickness datasets for Antarctica. Cryosphere, 7(1), $375-393$

Jansen D (2008) Evolution of Antarctic tabular icebergs. (PhD thesis, Alfred Wegener Institute for Polar and Marine Research, Bremerhaven)

Kennett BLN, Engdahl ER and Buland R (1995) Constraints on seismic velocities in the Earth from travel times. Geophys. J. Int., 122, 108-124

Kubat I, Sayed M, Savage SB and Carrieres T (2005) An operational model of iceberg drift. Int. J. Offshore Polar Eng., 15, 125-131

Kværna T and Ringdal F (1986) Stability of various $\mathrm{f}-\mathrm{k}$ estimation techniques. NORSAR Sci. Rep., 1-86/87, 29-40

Lenaerts JTM, Van den Broeke MR, Van de Berg WJ, Van Meijgaard E and Kuipers Munneke P (2012) A new, high-resolution surface mass balance map of Antarctica (1979-2010) based on regional atmospheric climate modelling. Geophys. Res. Lett., 39(4), L04501 (doi: 10.1029/2011GL050713)

Lien R, Solheim A, Elverhøi A and Rokoengen K (1989) Iceberg scouring and sea bed morphology on the eastern Weddell Sea shelf, Antarctica. Polar Res., 7, 43-57

Ligtenberg SRM, Kuipers Munneke P and Van der Broecke MR (2014) Present and future variations in Antarctic firn air content. Cryosphere, 8, 1711-1723 (doi: 10.5194/tc-8-1711-2014)

Long DG, Ballantyne J and Bertoia C (2002) Is the number of Antarctic icebergs really increasing? Eos, 83(42), 469, 474

MacAyeal DR and 13 others (2006) Transoceanic wave propagation links iceberg calving margins of Antarctica with storms in tropics and Northern Hemisphere. Geophys. Res. Lett., 33(17), L17502 (doi: 10.1029/2006GL027235)

MacAyeal DR, Okal EA, Aster RC and Bassis JN (2008a) Seismic and hydroacoustic tremor generated by colliding icebergs. J. Geophys. Res., 113(F3), F03011 (doi: 10.1029/2008JF001005)

MacAyeal DR, Okal MH, Thom JE, Brunt KM, Kim Y-J and Bliss AK (2008b) Tabular iceberg collisions within the coastal regime. J. Glaciol., 54(185), 371-386 (doi: 10.3189/ 002214308784886180)

MacAyeal DR, Wang Y and Okal EA (2015) Ambient seismic, hydroacoustic, and flexural gravity wave noise on a tabular iceberg. J. Geophys. Res. Earth Surf., 120, 200-211 (doi: 10.1002/2014JF003250)

Martin S, Drucker RS and Kwok R (2007) The areas and ice production of the western and central Ross Sea polynyas, 19922002, and their relation to the B-15 and C-19 iceberg events of 2000 and 2002. J. Mar. Syst., 68, 201-214 (doi: 10.1016/j. jmarsys.2006.11.008)

Martin S and 6 others (2010) Kinematic and seismic analysis of giant tabular iceberg breakup at Cape Adare, Antarctica. J. Geophys. Res., 115(B6), B06311 (doi: 10.1029/2009JB006700)

Matsumoto H and 7 others (2014) Antarctic icebergs: a significant natural ocean sound source in the Southern Hemisphere. Geochem. Geophys. Geosyst., 15, 3448-3458 (doi: 10.1002/ 2014GC005454)

Müller C, Schlindwein V, Eckstaller A and Miller H (2005) Singing icebergs. Science, 310(5752), 1299 (doi: 10.1126/ science.1117145)

Romanov YA, Romanova NA and Romanov P (2011) Shape and size of Antarctic icebergs derived from ship observation data. Antarct. Sci., 24(1), 77-87 (doi: 10.1017/S0954102011000538)

Schwarz JN and Schodlok MP (2009) Impact of drifting icebergs on surface phytoplankton biomass in the Southern Ocean: ocean colour remote sensing and in situ iceberg tracking. Deep-Sea Res. I, 56(10), 1727-1741 (doi: 10.1016/j.dsr.2009. 05.003)

Schweitzer J (2001) HYPOSAT - an enhanced routine to locate seismic events. Pure Appl. Geophys., 158, 277-289

Schweitzer J (2013) Automatic parameter extraction for threecomponent observations. NORSAR Sci. Rep., 2-2012, 36-49

Schweitzer J and 6 others (2012) Seismic arrays. In Bormann P ed. New Manual of Seismological Observatory Practice 2 (NMSOP2). Deutsches GeoForschungsZentrum GFZ, Potsdam, 1-80 (doi: 10.2312/GFZ.NMSOP-2_ch9)

Schweitzer J, Pirli M, Roth M and Kværna T (2014) TROLL - a new, very broadband seismic station in Antarctica. Seismol. Res. Lett., 85(4), 852-862 (doi: 10.1785/0220130223)

Silva TAM, Bigg GR and Nicholls KW (2006) Contribution of giant icebergs to the Southern Ocean freshwater flux. J. Geophys. Res., 111(C3), C03004 (doi: 10.1029/2004JC002843)

Smith KL Jr (2011) Free-drifting icebergs in the Southern Ocean: an overview. Deep-Sea Res. II, 58, 1277-1284 (doi: 10.1016/j. dsr2.2010.11.003)

Stephenson GR Jr, Sprintall J, Gille ST, Vernet M, Helly JJ and Kaufmann RS (2011) Subsurface melting of a free-floating Antarctic iceberg. Deep-Sea Res. II, 58, 1336-1345 (doi: 10.1016/j.dsr2.2010.11.009) 
Stuart KM and Long DG (2011a) Tracking large tabular icebergs using the SeaWinds Ku-band microwave scatterometer. DeepSea Res. II, 58(11-12), 1285-1300

Stuart KM and Long DG (2011b) Iceberg size and orientation estimation using SeaWinds. Cold Reg. Sci. Technol., 69, 39-51 (doi: 10.1016/j.coldregions.2011.07.006)

Talandier J, Hyvernaud O, Okal EA and Piserchia PF (2002) Longrange detection of hydroaoustic signals from large icebergs in the Ross Sea, Antarctica. Earth Planet. Sci. Lett., 203, 519-534

Talandier J, Hyvernaud O, Reymond D and Okal EA (2006) Hydroacoustic signals generated by parked and drifting icebergs in the Southern Indian and Pacific Oceans. Geophys. J. Int., 165, 817-834

Wingham DJ and 15 others (2006) CryoSat: a mission to determine the fluctuations in Earth's land and marine ice fields. Adv. Space Res., 37(4), 841-871

Zhan Z, Tsai VC, Jackson JM and Helmberger D (2014) Ambient noise correlation on the Amery Ice Shelf, East Antarctica. Geophys. J. Int., 196, 1796-1802

\section{APPENDIX: ICEBERG-TRACKING AGENCIES AND PRODUCTS}

Icebergs south of $60^{\circ} \mathrm{S}$ are tracked by the NIC (http://www. natice.noaa.gov/pub/icebergs/lceberg_Tabular.pdf) using satellite imagery, provided that their long axis is at least 10 nautical miles $(\sim 18.5 \mathrm{~km})$ and that their most recent sighting has occurred within the last 30 calendar days. The icebergs are also assigned a code name, consisting of an alphanumeric combination that reports the Antarctic quadrant where the iceberg originally calved from, the ice shelf from which the iceberg calved and the number of fragmentations of the original iceberg. The NIC reports iceberg positions on a weekly basis.

A more complete database containing daily positions of Antarctic icebergs (http://www.scp.byu.edu/data/iceberg/ database $1 . \mathrm{html}$ ) is provided by BYU, through the Scatterometer Climate Record Pathfinder (SCP) project. Iceberg tracking is based on the analysis of satellite scatterometer backscatter images (e.g. Long and others, 2002; Stuart and Long, 2011a,b), and the database also extends to icebergs not tracked by the NIC (e.g. Ballantyne, 2002). In this task, the SCP does not act as an operational agency, so there are no daily updates of iceberg positions; an online list of most recent iceberg positions (http://www.scp.byu.edu/current icebergs.html) is updated twice per week, whereas the full database is updated only a few times per year.

Tracking products can be supplemented by satellite imagery, such as the MODIS Antarctica mosaic (NASA Worldview: https://earthdata.nasa.gov/labs/worldview/, http://nsidc.org/data/iceshelves_images/index_modis.html) and, for time intervals prior to 8 April 2012, Envisat imagery (http://miravi.eo.esa.int/en/index.html). 